\title{
Diagnosis of Foot and Mouth Disease in Cattle and Buffaloes in Different Governorates of Egypt
}

\author{
Gamil Sayed Gamil Zeedan ${ }^{* 1}$, Ayman Hamid Mahmoud ${ }^{\mathbf{2}}$, Abeer Mostafa Abdalhamed ${ }^{\mathbf{1}}$ and Manal Hamdy Khafagi $^{\mathbf{1}}$ \\ ${ }^{1}$ Parasitology and Animals Diseases Department, National Research Centre,33 Bohouth St., Dokki, Giza, PO box 12622, Egypt \\ ${ }^{2}$ Biotechnology Department, Animal Health Institute, Dokki Giza, Egypt \\ *Corresponding author's Email: gamilzee@yahoo.com; (DORCiD: 0000-0002-2723-542X
}

\begin{abstract}
Foot and Mouth Disease (FMD) is a highly contagious disease affected cloven-hoofed animals which results in substantial economic losses. The present study was aimed to detect FMDV by different serological and molecular methods in cattle and buffaloes for providing an accurate and rapid diagnosis of FMD disease. 86 samples of tongue epithelium biopsies, fluid vesicles samples and saliva, as well as 86 coagulated and uncoagulated blood samples, were collected from 64 and 22 suspected cattle and buffaloes respectively in different governorates in Egypt, during August to December 2017. Serum samples were examined by 3ABC-ELISA for differentiating between infected and non-infected animals. While tissues biopsies and un-coagulated blood samples were examined by Sandwich ELISA, Reverse Transcriptase Polymerase Chain Reaction (RT-PCR) as well as Real-Time Reverse Transcriptase Polymerase Chain Reaction (rRT-PCR). FMDV porotypes were identified by rRT-PCR in suspected cattle and buffaloes samples to FMDV serotype A, O and SAT2 and results showed that 54 samples positive for FMDV different serotypes while FMDV serotype differentiation in tissues biopsy of cattle were 18 (28.12\%), 12 $(18.75 \%), 3(4.68 \%)$ and $4(6.25 \%)$. Also, the positive results of tissue samples from buffaloes examined by RTPCR were $9(40.09 \%), 4(6.25 \%), 2(9.09 \%)$ and $2(9.09 \%)$ for O, SAT2, serotype A and mixed serotypes respectively by different tests. The rRT-PCR provided an accurate and rapid laboratory diagnosis of FMDV as well as RT-PCR, and 3ABC- ELISA were given nearly the same results. Although the rRT-PCR generated results in less than $6 \mathrm{~h}$ and this is an important feature when definitive diagnostic results required in a short timescale during emergencies. Also, this study demonstrated the current situation of circulation FMDV type A, O, and SAT2 serotypes in cattle and buffaloes in Egypt.
\end{abstract}

Key words: 3 ABC-ELISA, Buffaloes, Cattle, Foot and mouth disease, Real-time reverse transcriptase polymerase chain reaction

\section{INTRODUCTION}

Foot and Mouth Disease (FMD) is an important highly contagious transboundary viral disease that affects cloven-hoofed domesticated and wild animals in Asia and Africa (Grubman and Baxt, 2004; Sobhy et al., 2018; Diab et al., 2019). FMDV is non-enveloped, spherical shape ranged from $20-30 \mathrm{~nm}$ in diameter, small virus with an icosahedral capsid composed of four structural proteins (VP1, VP2, VP3, and VP4), which surround a single-stranded positive-sense RNA genome is an 8.4-kilobase (Brooksby, 1958; Aktas et al., 2015; Jamal and Belsham, 2018). FMD virus belongs to genus Aphthovirus, family Picornaviridae (Knowles et al., 2012; Salam et al., 2014). All serotypes give rise to a similar disease but each serotype does not confer immunity against another (Beck and Strohmaier, 1987; Stram et al., 1995; Lloyd-Jones et al., 2017). FMD virus serotypes O, A and Asia1 are endemic or cause periodical FMD outbreaks in the Middle East and serotypes O and A cause FMD outbreaks in North Africa (Knowles et al., 2012). In Egypt from 1964 to 2005, only serotype O was recognized, but in 2006, FMDV serotype A outbreak was occurred in cattle and FMDV serotype (A) was identified as A/Egy/2006 and this strain has more than $90 \%$ nucleotide identity with A/KEN/98, $\mathrm{A} / \mathrm{ETH} / 92$, and $\mathrm{A} / \mathrm{KEN} / 05$, and all topotypes are closely related. It's though introduction in Egypt from East Africa was probably through imported live cattle from Ethiopia (via sea-route) (Ahmed et al., 2012; Jamal and Belsham, 2018). The dramatic upsurge FMD serotype SAT2 outbreaks occurred in cattle, water buffalo and small ruminants with severe clinical signs of FMD in Egypt in 2012 (Kandeil et al., 2013). Serotypes O, A and SAT2 have been detected in this country since 2013 (Sobhy et al., 2018).

FMD disease is the most important restraint to international trade of animal and animal's byproduct. FMD is highly infectious and can be spread by infected animals through aerosols, contact, contaminated farming equipment, vehicles, clothing or feed, and by domestic and wild predators (Salam et al., 2014). The FMDV is associated with sudden death in young calves without observable clinical signs (Yang et al., 2013; Diab et al., 2019). The accurate diagnosis of FMDV is 
important for controlling and eradication of disease in endemic countries including Egypt. It is necessary to conduct laboratory diagnosis of any suspected case of FMD to confirm the disease, includes virus isolation, genome identification techniques such as polymerase chain reaction (PCR) assays and serological tests such as the virus neutralization test, nonstructural protein (NSP)-ELISA (3ABC-ELISA) and Liquid Phase Blocking (LPB)-ELISA for screening the antibodies of FMDV serotype were applied (EL-Kholy et al., 2007; OIE, 2008; EL-Shehawy et al., 2011; FAO, 2012; El-Khabaz and Al-Hosary, 2017). The Polymerase Chain Reaction (PCR) is a quick and more accurate approach and is appropriate to be used with various types of clinical samples. The sensitivity of this method is many times higher than virus isolation which was recognized as "gold standard" in FMDV recognition (OIE, 2012). There are different methods of nucleic acid detection including real-time reverse transcription-polymerase chain reaction (rRT-PCR) which considering as one of the approaches used for detection and typing of FMDV serotypes (El Bahgy and Mustafa, 2018). The difficulties in controlling of cattle movement transboundary and also controlling this movement from neighboring countries to Egypt lead to contact with Egyptian native and hybrid herds and may provide a mechanism for spreading the FMDV. However, the roles of transboundary and animal movement in epidemiology of FMDV in Egypt have not been studied yet, so the vaccination was the only way to control the FMD disease in Egypt (Jamal and Belsham, 2018). Rapid identification of FMDV serotypes especially during outbreaks is very important in order to use the appropriate emergency vaccine and determine the origin of infection (Radostitis et al., 2007 and OIE, 2009). The present study aimed to investigate and determine FMDV serotype responsible for the reemerging outbreaks in Egypt during 2017 by serological and Real-time Reverse Transcription-Polymerase Chain Reaction (rRT-PCR) assays.

\section{MATERIALS AND METHODS}

\section{Ethical approval}

All samples were collected as per standard procedure without giving any stress or harm to the animals. The work was done according to the guidelines of the National Institutes of Health Guide (Sohair et al., 2016). All laboratory work was done at the National Research Centre and in Animals Health Institute biosafety II laboratory also, oral permission of the animal owners from the individual or private animals farms, before clinical samples from cattle were taken under the supervision of professional veterinarian according to the Egyptian general organization of veterinary services, ministry of agriculture

\section{Study area and animals}

This study was conducted in cattle and buffaloes with FMD signs in different governorates of Egypt during August to December 2017. FMD clinical signs, high fever $\left(40^{\circ} \mathrm{C}-41^{\circ} \mathrm{C}\right)$, vesicles, ulcerations on the gum, dorsum of plate, tongue with excessive profuse salivation, foot lesions in interdigital space with ulcerations lead to lameness, in dairy animals, vesicles and ulcerations on udder and teat. All signs ranged from sever, moderate to mild according to the immunity and health conduction of animals.

\section{Samples collection}

Total 86 samples (whole blood samples and tongue tissues biopsy samples) were collected from suspected animals (64 cattle male or female, foreign or native breed and 22 buffaloes) located at different governorates in Egypt as shown in figure 1. The biopsies from tongue epithelium, lips vesicles and saliva were collected in transport medium which was a mixture of equal amounts of sterile glycerol and phosphate buffered saline. The $\mathrm{pH}$ range was 7.2-7.4 with antibiotics and processed according to Callahan et al. (2002). Beside whole blood without anti-co agglutinate were collected for detection FMDV antibodies. All samples were kept on ice till reached to the lab and then prepared and stored in $-20^{\circ} \mathrm{C}$ until used.

\section{Serological tests}

3ABC-enzyme-linked immunosorbent assay (3ABC-ELISA)

(3ABC-ELISA kit (IDEXX FMD 3ABC Bo-Ov, Spain) for detection of non-structural polyprotein of FMD antigen antibody in cattle and buffaloes sera was used and followed by the manufacturer instructions. Whole blood samples without anticoagulants were collected from suspected animals after sera separation stored at $-40^{\circ} \mathrm{C}$ or examined after appropriate dilution by 3ABC- FMD antigen using. The 3ABC-ELISA was developed under standard laboratory conditions with all incubation steps at $37^{\circ} \mathrm{C}$ with gentle shaking. Plates were washed three times between incubation steps with washing buffered (phosphate-buffered saline $\mathrm{pH} 7.2$ tween 0.05\%). Briefly, 96-well coated with poly FMDV $3 \mathrm{ABC}$ nonstructural polyprotein, $50 \mu \mathrm{L}$ of the test sera samples or control sera were added at a 1: 50 dilutions (in blocking buffer) and the plate was incubated for $30 \mathrm{~min}$. Control sera and the plate incubated for an additional 30min. After washing, anti-bovine horse radish peroxidase conjugate was added $(50 \mu \mathrm{L} /$ well in blocking buffer) and incubated for $1 \mathrm{~h}$. After washing, $50 \mu \mathrm{L} /$ well of 3,3',5,5'-Tetramethylbenzidine (TMB) substrate were added and the reaction stopped 
after $10 \mathrm{~min}$ at room temperature by the addition of $50 \mu \mathrm{L} /$ well of $1 \mathrm{~mol} / \mathrm{L} \mathrm{H} 2 \mathrm{SO} 4$ and the absorbance of each well at $450 \mathrm{~nm}$ measured on an ELISA reader after blanking. Sera were tested duplicate or triplicate and the final result was expressed as the mean value. Each plate contained four replicates of the positive and negative controls. Results were presented with percentage and values $\geq 30 \%$ were considered positive, $<20 \%$ as negative and samples between $>20 \%$ and $<30 \%$ were considered suspicious.

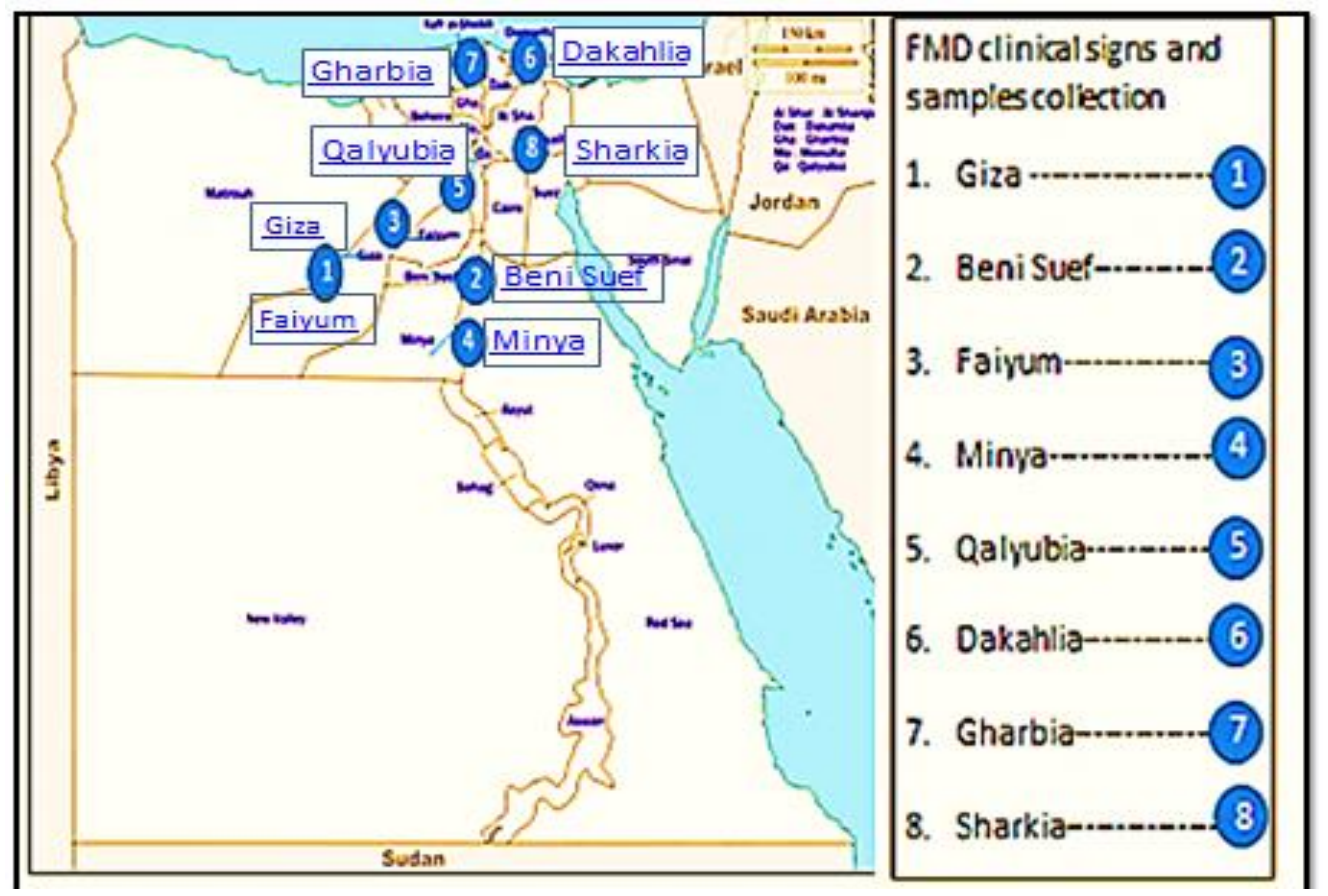

Figure 1. The geographical distribution of infected cattle's and buffaloes with foot and mouth disease clinical signs in different governorates of Egypt in 2017. Total 86 samples (whole blood samples and tongue tissues biopsy samples) were collected from suspected animals (64 cattle male or female, foreign or native breed and 22 buffaloes) located at different governorates in Egypt.

\section{Sandwich-ELISA}

Detection of FMDV serotypes presence in infected biopsy samples of cattle and buffaloes (tongue tissues biopsies, vesicles and saliva), was done by Sandwich-ELISA (Sn- ELISA), (Brescia, Italy and Pirbright, UK). Supernatants of the homogenized clinical tissue materials were tested in an in-house serotype differentiating antigen detection ELISA to detect the virus serotype involved in the outbreaks. Briefly, dilute coating sera for each serotype, as manual instruction, with 0.05 mole (mol) carbonate buffer ( $\mathrm{pH}$ 9.6). 96-well flat-bottom plate was coated with $50 \mu \mathrm{l} /$ well of each antiserum at $4^{\circ} \mathrm{C}$ overnight. The plates were washed three times washing buffer. The tested samples were added to the wells and incubated for $1 \mathrm{~h}$ at $37^{\circ} \mathrm{C}$. The plates were washed three times with Phosphate-Buffered Saline (PBS), dispense 50 $\mu$ l of blocking buffer and positive and negative controls dispense $50 \mu \mathrm{l}$ of respective controls provided incubate at $37^{\circ} \mathrm{C}$ for 1 hour with gentle shaking followed by washed three times by washing buffer. All serum samples diluted 1:50, as suggested, with blocking buffer. $50 \mu \mathrm{l}$ of peroxidase-labeled was added to the wells and incubated for $45 \mathrm{~min}$ at $37^{\circ} \mathrm{C}$. Afterward the plates were washed three times and $50 \mu \mathrm{l}$ of o-phenylenediamine-H2O 2 substrate was added to the plates, which were then incubated in the dark for $15 \mathrm{~min}$ at room temperature. The reaction was stopped with $50 \mu \mathrm{l}$ of $1.25 \mathrm{M}$ $\mathrm{H} 2 \mathrm{SO} 4$, and the optical density (OD) was measured with an ELISA reader at $492 \mathrm{~nm}$.

\section{Conventional RT-PCR \\ RNA extraction}

The Viral RNA was extracted by RNA Mini kit (Qiagen, Germany) from blood with EDTA and homogenized tissue samples (50-100 $\mathrm{mg}$ ) according to the manufacturer instructions.

\section{Reverse transcription polymerase hain reaction}

One-step Reverse Transcription Polymerase Chain Reaction (RT-PCR) of FMDV was carried out as described by the manufacturer's protocol to perform the reverse transcription and subsequent PCR by one-step RT-PCR (Qiagen, Germany). The primer sequences were as listed in table 1 . Amplification reactions ( $25 \mu \mathrm{L}$ reaction mixture) were performed at the following conditions: $50^{\circ} \mathrm{C}$ for $30 \mathrm{~min}$ for reverse transcription and initial denaturation at $95{ }^{\circ} \mathrm{C}$ for 15 min, then 35 cycles consisted of $94{ }^{\circ} \mathrm{C}$ for one min for denaturation followed by annealing for one min at $52{ }^{\circ} \mathrm{C}$ for serotype $\mathrm{O}$ and SAT2 while for serotype A, the reaction was runed at $54{ }^{\circ} \mathrm{C}, 55^{\circ} \mathrm{C}$, respectively. The extension was done 
at $72{ }^{\circ} \mathrm{C}$ for one min followed by one final extension step of $10 \mathrm{~min}$ at $72{ }^{\circ} \mathrm{C}$. The amplicons were analyzed by $1.5 \%$ agarose gel electrophoresis.

Table 1. Oligonucleotide primers used for detection of foot and mouth disease virus different serotypes in affected cattle and buffaloes

\begin{tabular}{|c|c|c|c|}
\hline Primer & Sequence $\left(5^{\prime}\right.$ to $\left.3^{\prime}\right)$ & Target gene & size bp \\
\hline FMDV-All serotype & $\begin{array}{l}\text { F 5-GCC TGG TCT TTC CAG GTC T-3 } \\
\text { R 5-CCA GTC CCC TTC TCA GAT C-3 }\end{array}$ & $\begin{array}{l}\mathrm{P} 1 \\
\mathrm{P} 2\end{array}$ & 216-bp \\
\hline FMDV-O & $\begin{array}{l}\text { F } 55^{\prime} \text {-AGC TTG TAC CAG GGT TTG GC-3' } \\
\text { R 5'- GCT GCC TAC CTC CTT CAA -3' }\end{array}$ & $2 \mathrm{~B}$ & $402-b p-$ \\
\hline FMDV-SAT & $\begin{array}{l}\text { F 5-CCA CAT ACT ACT TTT GTG ACC TGG A-3 } \\
\text { R 5-ACA GCG GCC ATG CAC GAC AG-3 }\end{array}$ & $\begin{array}{l}\text { ID } \\
2 \mathrm{~B}\end{array}$ & $\begin{array}{c}715- \\
730 \mathrm{bp}\end{array}$ \\
\hline FMDV-SAT2 & $\begin{array}{l}\text { F 5'-GAA GGG CCC AGG GTT GGA CTC-3 } \\
\text { R 5'-CAC TGC TAC CACTCR GAG TG-3' }\end{array}$ & $\begin{array}{l}\text { ID } \\
2 \mathrm{~B}\end{array}$ & 880 bp \\
\hline FMDV-A & 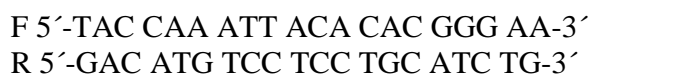 & $\begin{array}{l}\text { VP3 } \\
2 B\end{array}$ & $\begin{array}{l}863- \\
866 \mathrm{bp}\end{array}$ \\
\hline
\end{tabular}

\section{Real-time reverse-transcriptase polymerase chain reaction}

RNA extraction was carried out using the QI Aamp viral RNA kit (Qiagen, Germany) according to Reid et al. (2003). Primer pair (PorR/PorF) for real-time RT-PCR were synthesized by Bio Basic, Canada. Por F (5'- CCT ATG AGA ACA AGC GCA TC -3') and Por R (5’- CAA CTT CTC CTG TAT GGT CC -3') were derived from FMDV. RTPCR was performed using QT SYBR Green RT-PCR Kit (Qiagen, Germany) as the manufacturer's instructions. The cycling parameters were $50{ }^{\circ} \mathrm{C}$ for $30 \mathrm{~min}$ and $95{ }^{\circ} \mathrm{C}$ for $15 \mathrm{~min}$, then 30 cycles consisted of $94{ }^{\circ} \mathrm{C}$ for $15 \mathrm{~s}, 55^{\circ} \mathrm{C}$ for $30 \mathrm{~s}$ and $72{ }^{\circ} \mathrm{C}$ for $30 \mathrm{~s}$. Negative control specimens were involved. Thermocycler Rotor-Gene Q (Qiagen, Germany) was used for real-time detection of FMDV by RT-PCR according to Reid et al. (2003).

\section{Statistical analysis}

The results were analyzed using the Statistical Package for Social Sciences (SPSS, version 16, Chicago, Illinois, USA). Serum and samples of tissue biopsies were calculated by the chi-square at $\mathrm{P}<0.05$ is considered to be statistically significant.

\section{RESULTS AND DISCUSSION}

Foot and mouth disease is one of the most destructive viral diseases for livestock animals which is endemic in Egypt and usually occurs as an outbreak because of its nature. Rapid diagnosis would play a crucial role in controlling programs (Kandeil et al., 2013; El-Khabaz and Al-Hosary, 2017). Although, the presence of a locally trivalent vaccine against FMDV serotypes A, O and SAT2, annually outbreaks are occurring in cattle and buffaloes throughout Egypt (Khodary et al., 2018; Diab et al., 2019). The FMDV strains circulated among cattle and buffalo herds in Egypt during 2013 (Abd El Wahed et al., 2013). The clinical signs of present study in cattle and buffaloes during summer 2017 were similar to FMD signs include fever $40-41^{\circ} \mathrm{C}$, ropy salivation, vesicles and erosions in gums, dorsum of the tongue and in inter-digital spaces of cattle's and buffaloes claws as the characteristic signs of FMD and these clinical observations are agreed and recorded by many previous researches (Elhaig and Elsheery, 2014; Aktas et al., 2015; El-Khabaz and Al-Hosary, 2017). Detection of FMDV infection in cattle and buffaloes by 3ABC-ELISA were 54 out of 86 serum samples (37 and 17) positive for nonstructural protein antibody in field serum samples by 3ABC-ELISA indicated active FMDV infection respectively. Also, negative serum samples mean, no infection or animals may be vaccinated with FMDV vaccine as showed in figure 1 and figure 2 and these results were agreed with (King et al., 2006; Rady et al., 2014).

Epithelial tissues contained an abundance of the FMDV which detected by Sn-ELISA for differentiation of FMDV serotypes (EL-Shehawy et al., 2011; Longjam et al., 2011; Khodary et al., 2018). Differentiation of FMDV serotypes by Sn-ELISA in tissues biopies of cattle were 12 (18.75\%), $18(28.12 \%), 3(4.68 \%)$ and $4(6.25 \%)$ positive for A, O, SAT2 and mixed coinfection with three serotypes respectively. Also, in buffaloes, the positive precent of samples of tissue biopsy were 4 (6.25\%) for serotype SAT2, 9 (40.09\%) for serotype O, 2 (9.09\%) for serotype A and 2 (9.09\%) for mixed infection with three serotypes (O, A and SAT2) as shown in table 2 and figure 3. 


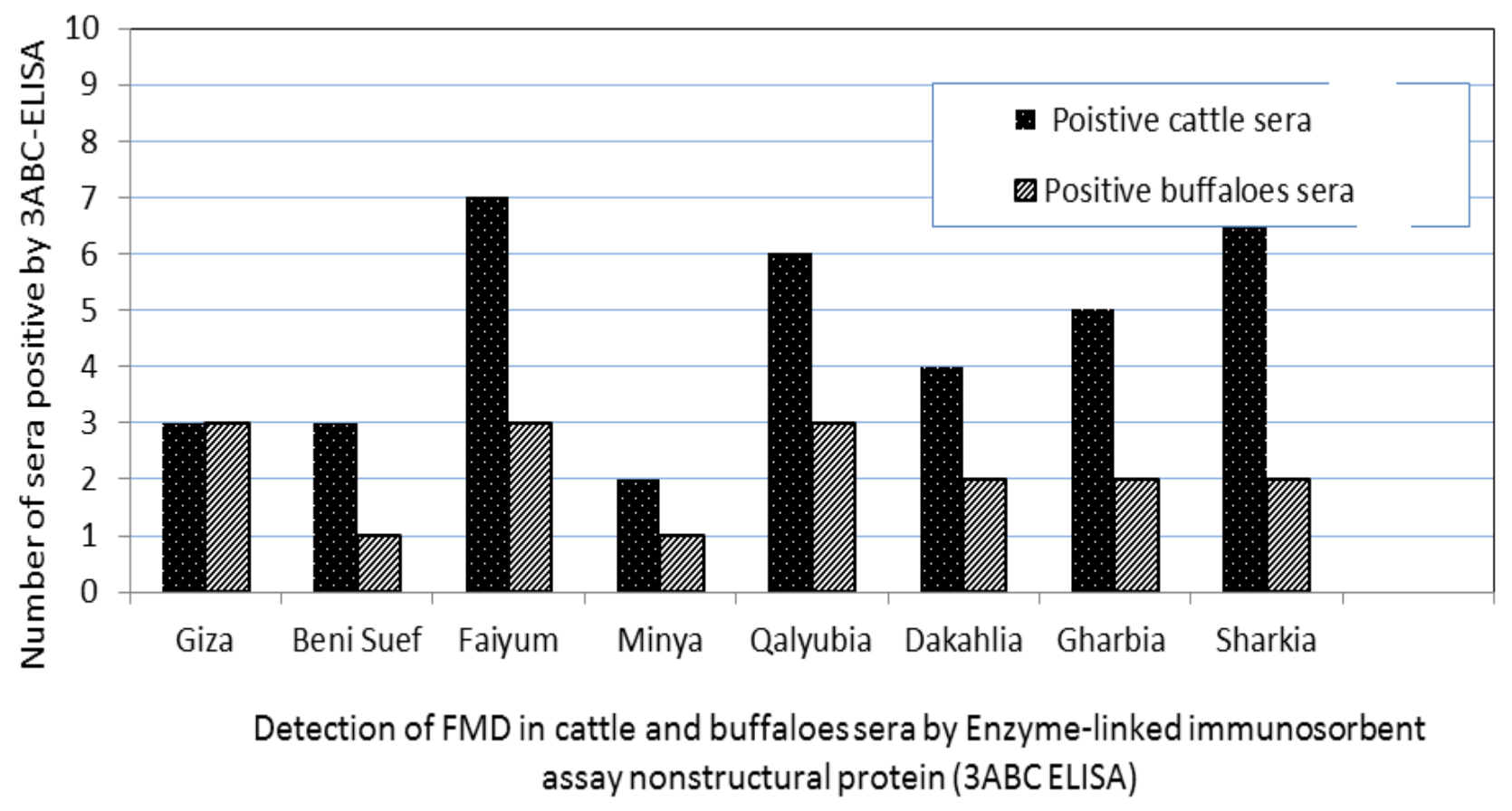

Figure 2. Detection of foot and mouth disease virus in cattle and buffaloes of different governorates of Egypt examined by Enzyme-linked immunosorbent assay nonstructural protein (3ABC ELISA)

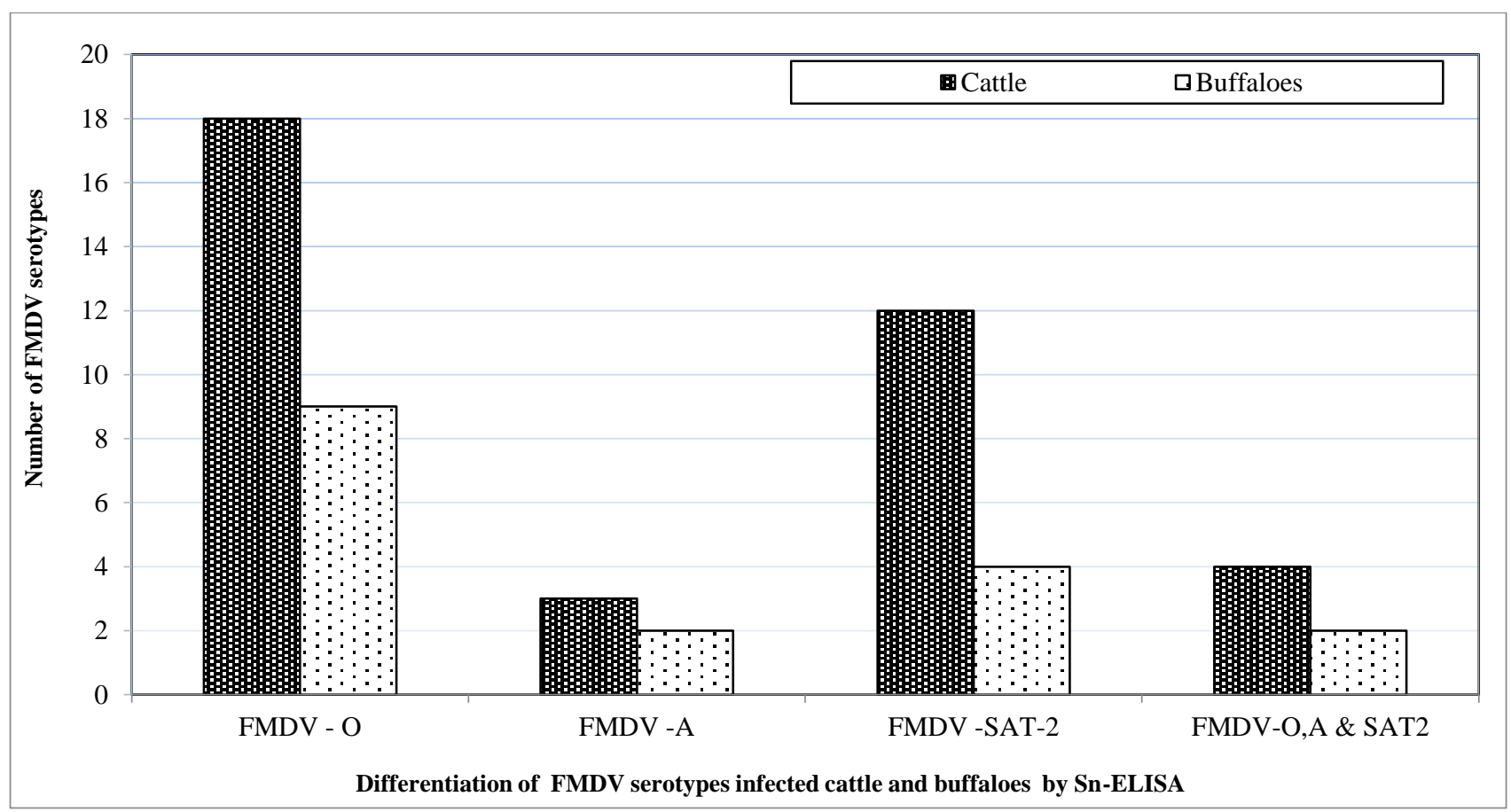

Figure 3. The differentiation of foot and mouth disease virus serotypes A, O and SAT2 in infected cattle and buffaloes at different governorates in Egypt by sandwich-ELISA. Foot and mouth disease virus serotype SAT-2: Positive results for FMDV serotype SAT-2 infected cattle and buffaloes; FMDV serotype O: Positive results for FMDV serotype O infected cattle and buffaloes; FMDV serotype A: Positive results for FMDV serotype A infected cattle and buffaloes; Mixed FMDV serotype A, O and SAT-2: Positive results for different FMDV serotype A, O; SAT-2 mixed infected cattle and buffaloes

The obtained results confirmed that the FMDV serotypes were SAT2, A, and O which circulated in Egypt yet. The serotype $\mathrm{O}$ is predominant FMDV serotype in Egypt as shown in table 2 and figure 3 and this result was agreed with (Domingo and Holland, 1997; Carrillo et al., 2005). The molecular identification by RT-PCR used universal primer set P1/P2 detected the FMDV regardless to the serotype, the specific band appeared at 216-bp, followed by specific primer for each serotypes O, A and SAT2 are endemic in Egypt as presented in table 1 and figure 4 this finding was agreed with many previous reports (Carrillo et al., 2005; Vallat, et al., 2017; Sobhy et al., 2018), that stated the endemic infections have been occurred more than one serotypes. 
Table 2. Detection of different foot and mouth diseases virus serotypes by sandwich-ELISA in infected cattle and buffaloes specimens in different governorates of Egypt

\begin{tabular}{|c|c|c|c|c|c|c|c|c|c|c|c|c|}
\hline \multirow{3}{*}{ Location } & \multicolumn{2}{|c|}{$\begin{array}{c}\text { clinical samples biopsies or } \\
\text { sera }\end{array}$} & \multicolumn{10}{|c|}{ Sn- ELISA } \\
\hline & \multirow{2}{*}{ Cattle } & \multirow{2}{*}{ Buffaloes } & \multicolumn{2}{|c|}{$\begin{array}{c}\text { Food and Mouth Disease Virus } \\
\text { serotypes } O(\%)\end{array}$} & \multicolumn{2}{|c|}{$\begin{array}{l}\text { Food and Mouth Disease } \\
\text { Virus serotypes A (\%) }\end{array}$} & \multicolumn{2}{|c|}{$\begin{array}{l}\text { Food and Mouth Disease } \\
\text { Virus serotypes SAT-2 (\%) }\end{array}$} & \multicolumn{2}{|c|}{$\begin{array}{l}\text { Mixed infection different } \\
\text { serotypes }\end{array}$} & \multicolumn{2}{|c|}{ Total Positive (\%) } \\
\hline & & & Cattle & Buffaloes & Cattle & Buffaloes & Cattle & Buffaloes & Cattle & Buffaloes & Cattle & Buffaloes \\
\hline Giza & 8 & 3 & $2(25)$ & $2(66.6)$ & - & - & $1(12.5)$ & - & & $1(33.33)$ & $3(37.5)$ & $3(100)$ \\
\hline Beni Suef & 7 & 2 & - & - & - & - & $3(42.8)$ & $1(50)$ & & - & $3(42.85)$ & $1(50)$ \\
\hline Faiyum & 9 & 4 & $3(33.33)$ & $2(50)$ & $1(11.11)$ & $1(25)$ & $2(22.22)$ & - & $1(11.11)$ & - & $7(66.66)$ & $3(75)$ \\
\hline Minya & 6 & 2 & $1(16.66)$ & $1(50)$ & & & $1(16.66)$ & - & & - & $2(33.33)$ & $1(50)$ \\
\hline Qalyubia & 8 & 4 & $3(37.5)$ & $1(25)$ & $1(12.5)$ & & $1(12.5)$ & $1(25)$ & $1(12.5)$ & $1(25)$ & $6(83.33)$ & $3(50)$ \\
\hline Dakahlia & 7 & 2 & $2(28.57)$ & $1(50)$ & - & $1(50)$ & $2(28.57)$ & - & & - & $4(57.14)$ & $2(100)$ \\
\hline $\begin{array}{l}\text { Gharbia } \\
\text { Sharkia }\end{array}$ & $\begin{array}{c}11 \\
8\end{array}$ & $\begin{array}{l}3 \\
2\end{array}$ & $\begin{array}{l}3(27.27 \%) \\
4(50)\end{array}$ & $\begin{array}{l}1(33.33) \\
1(50)\end{array}$ & $\begin{array}{c}- \\
1(12.5)\end{array}$ & - & $\begin{array}{l}1(0.09 \%) \\
1(12.5)\end{array}$ & $\begin{array}{c}1(33.33) \\
1(50)\end{array}$ & $\begin{array}{c}1(0.09 \%) \\
1(12.5)\end{array}$ & - & $\begin{array}{l}5(45.45) \\
7(75)\end{array}$ & $\begin{array}{l}2(66.66) \\
2(100)\end{array}$ \\
\hline Total & 64 & 22 & $18(28.12)$ & $9(40.09)$ & $3(4.68)$ & $2(9.09)$ & $12(18.75)$ & $4(16.66$ & $4(6.25)$ & $2(9.09)$ & $37(51.5)$ & 17(59.09) \\
\hline
\end{tabular}

Sn- ELISA: Sandwich enzyme linked immunosorbent assay; FMDV: Foot and mouth disease virus

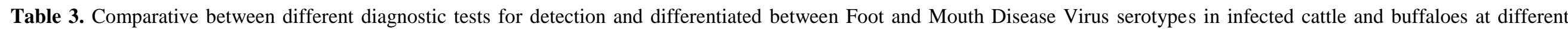
governorates in Egypt in 2017.

\begin{tabular}{|c|c|c|c|c|c|c|c|c|c|c|c|c|c|c|c|c|}
\hline \multirow[b]{2}{*}{$\begin{array}{l}\text { Animals } \\
\text { species }\end{array}$} & \multirow[b]{2}{*}{$\begin{array}{c}\text { number of } \\
\text { tissue biopsies } \\
\text { collected } \\
\text { during } \\
\text { outbreaks }\end{array}$} & \multicolumn{5}{|c|}{$\begin{array}{c}\text { Reverse transcription polymerase chain reaction (RT- } \\
\text { PCR) }\end{array}$} & \multirow[b]{2}{*}{$\begin{array}{c}\text { ELISA used } \\
\text { nonstructura } \\
\text { I protein } \\
\text { (3ABC- } \\
\text { ELISA) }\end{array}$} & \multicolumn{4}{|c|}{$\begin{array}{c}\text { Sandwich enzyme linked immunosorbent } \\
\text { assay (Sn-ELISA) }\end{array}$} & \multicolumn{5}{|c|}{ Real-Time reverse transcriptase PCR (rRTPCR) } \\
\hline & & $\begin{array}{c}\text { FMDV } \\
\text { universal } \\
\text { primers } \\
\text { (U- FMDV) }\end{array}$ & $\begin{array}{l}\text { FMDV } \\
\text { SAT-2 }\end{array}$ & $\begin{array}{l}\text { FMDV } \\
\text { O }\end{array}$ & $\begin{array}{l}\text { FMDV } \\
\text { A }\end{array}$ & $\begin{array}{c}\text { FMDV } \\
\text { mixed } \\
\text { infection } \\
\text { SAT2, O } \\
\text { and A } \\
\end{array}$ & & $\begin{array}{l}\text { FMDV } \\
\text { SAT } 2\end{array}$ & $\begin{array}{l}\text { FMDV } \\
\text { O }\end{array}$ & $\begin{array}{l}\text { FMDV } \\
\text { A }\end{array}$ & $\begin{array}{c}\text { FMDV mixed } \\
\text { infection } \\
\text { SAT2, O and } \\
\text { A }\end{array}$ & $\begin{array}{c}\text { FMDV } \\
\text { universal } \\
\text { primers } \\
\text { (U- FMDV) }\end{array}$ & $\begin{array}{l}\text { FMDV } \\
\text { - SAT } 2\end{array}$ & $\begin{array}{l}\text { FMDV } \\
-O\end{array}$ & $\begin{array}{c}\text { FMDV } \\
-A\end{array}$ & $\begin{array}{c}\text { FMDV } \\
\text { mixed } \\
\text { infection } \\
\text { SAT2,O anc } \\
\text { A } \\
\end{array}$ \\
\hline Cattle & 64 & 37 & 12 & 18 & 3 & 4 & 37 & 12 & 18 & 3 & 4 & 37 & 12 & 18 & 3 & 4 \\
\hline Buffaloes & 22 & 17 & 4 & 9 & 2 & 2 & 17 & 4 & 9 & 2 & 2 & 17 & 4 & 9 & 2 & 2 \\
\hline Total & 86 & 54 & 16 & 27 & 5 & 6 & 54 & 16 & 27 & 5 & 6 & 54 & 16 & 27 & 5 & 6 \\
\hline
\end{tabular}

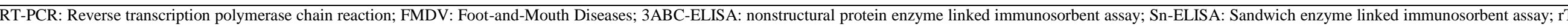

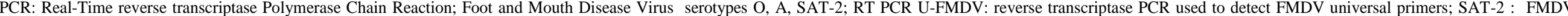
serotype SAT-2; S-O: FMDV serotype O; S-A: FMDV serotype A; SAT-2, O and A: infected animals different serotypes of FMDV (Mixed infection). 


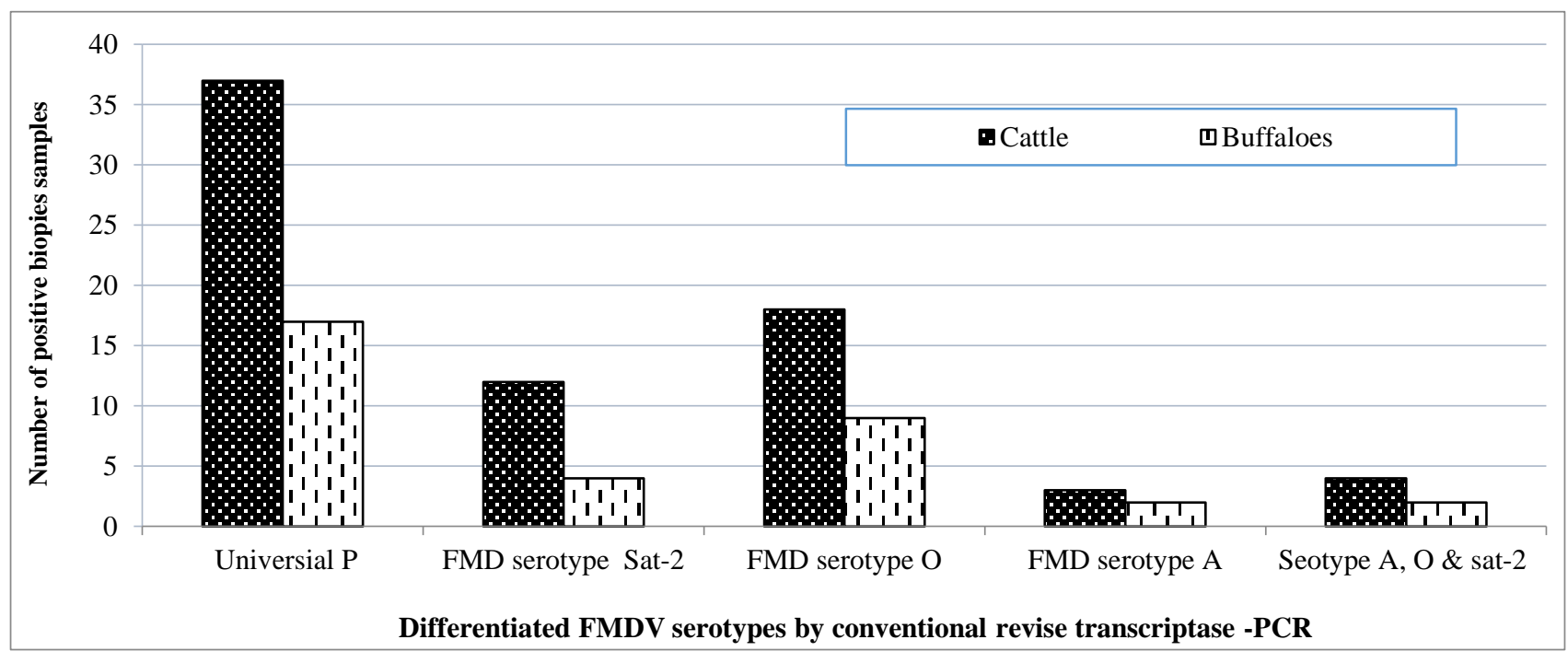

Figure 4. Detection of different foot and mouth disease virus serotypes in tissue samples of bovine by conventional revise transcriptase -PCR in different governorates of Egypt

Universal p: positive results of reverse transcription polymerase chain reaction using universal primer in specimen of cattle and buffaloes; Fserotype SAT-2: Positive results for FMDV serotype SAT-2 infected cattle and buffaloes specimens; Foot and mouth disease virus serotype O: Positive results for FMDV serotype O infected cattle and buffaloes specimens; FMDV serotype A: Positive results for FMDV serotype A infected cattle and buffaloes specimens. The examination of 86 tissue samples for FMDV from cattle and buffaloes by RT-PCR using universal primers for FMDV were 54 tissue samples positive for FMDV different serotypes but when used specific primers with RT-PCR for differentiation FMDV serotype in tissues biopsy of cattle were $18(28.12 \%), 12(18.75 \%), 3(4.68 \%)$ and $4(6.25 \%)$ for serotypes O, SAT2, A and mixed coinfection with three serotypes respectively. Also, the, positive results of tissue samples from buffaloes examined by RT-PCR were $9(40.09 \%), 4(6.25 \%), 2(9.09 \%)$ and $2(9.09 \%)$ for O, SAT2 , serotype A and mixed serotypes respectively, as illustrated in figure 4 and this finding was in agree with (Locher et al., 1995; Carrillo et al., 2005; Paixao et al., 2008; Shawky et al., 2013; Sobhy et al., 2014).

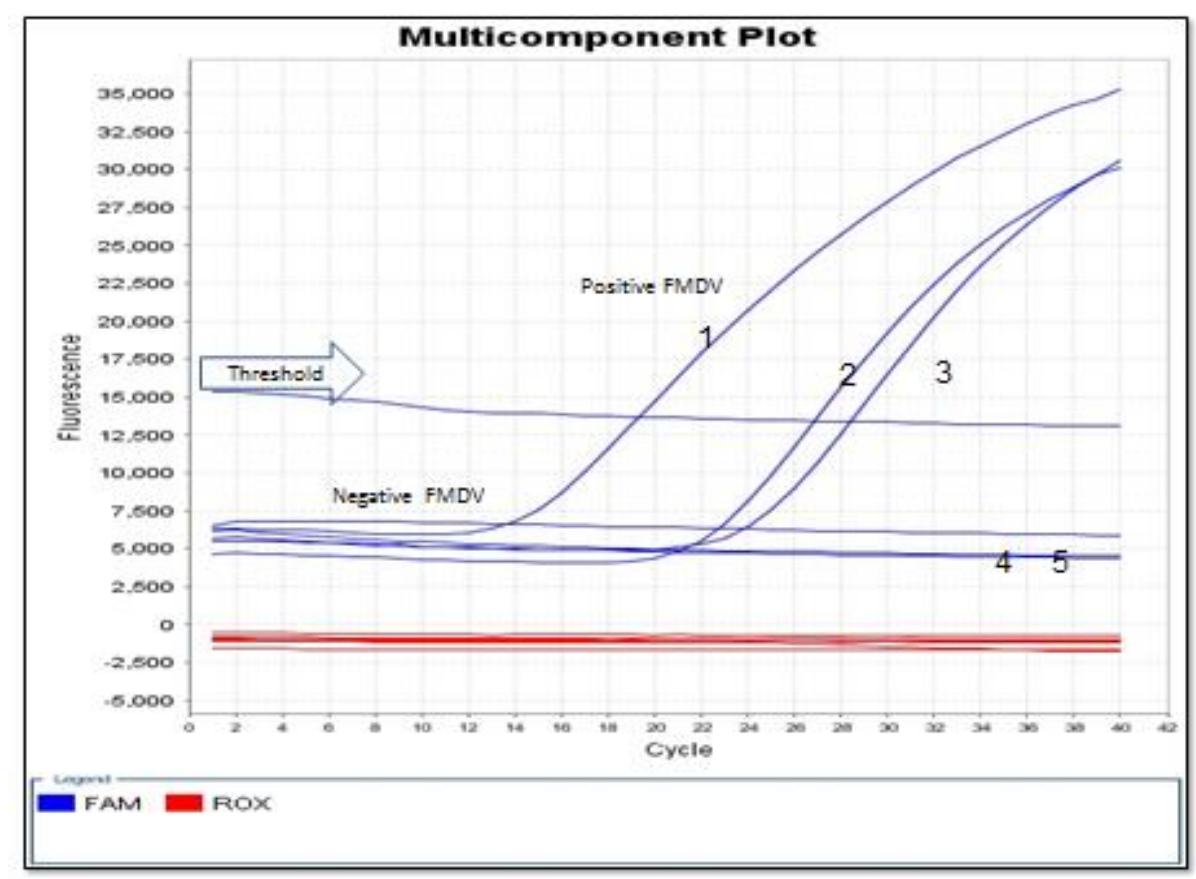

Figure 5. Tissues biopsies samples collected from cattle and buffaloes suspected to FMD in Egypt on 2017. Ct 1 : Postive control for all Foot -and Mouth Disease Virus (FMDV)serotypes using univesial primers; Ct 2,3 ,4 and 5: Tested tissues biopsies samples colected from cattle and buffaloes during FMDoutbeaks. Fam-labeled probes: FAM based probe complementary to only one of the genes and SYBR Green I as an intercalating dye; Ct: cycle threshold; ROX0: normalization $0.5 \mu 1$ ROX (5x concentration) (6-Carboxyl-X-Rhodamine max - 610nm) can inhibit PCR if the concentration is too high. 


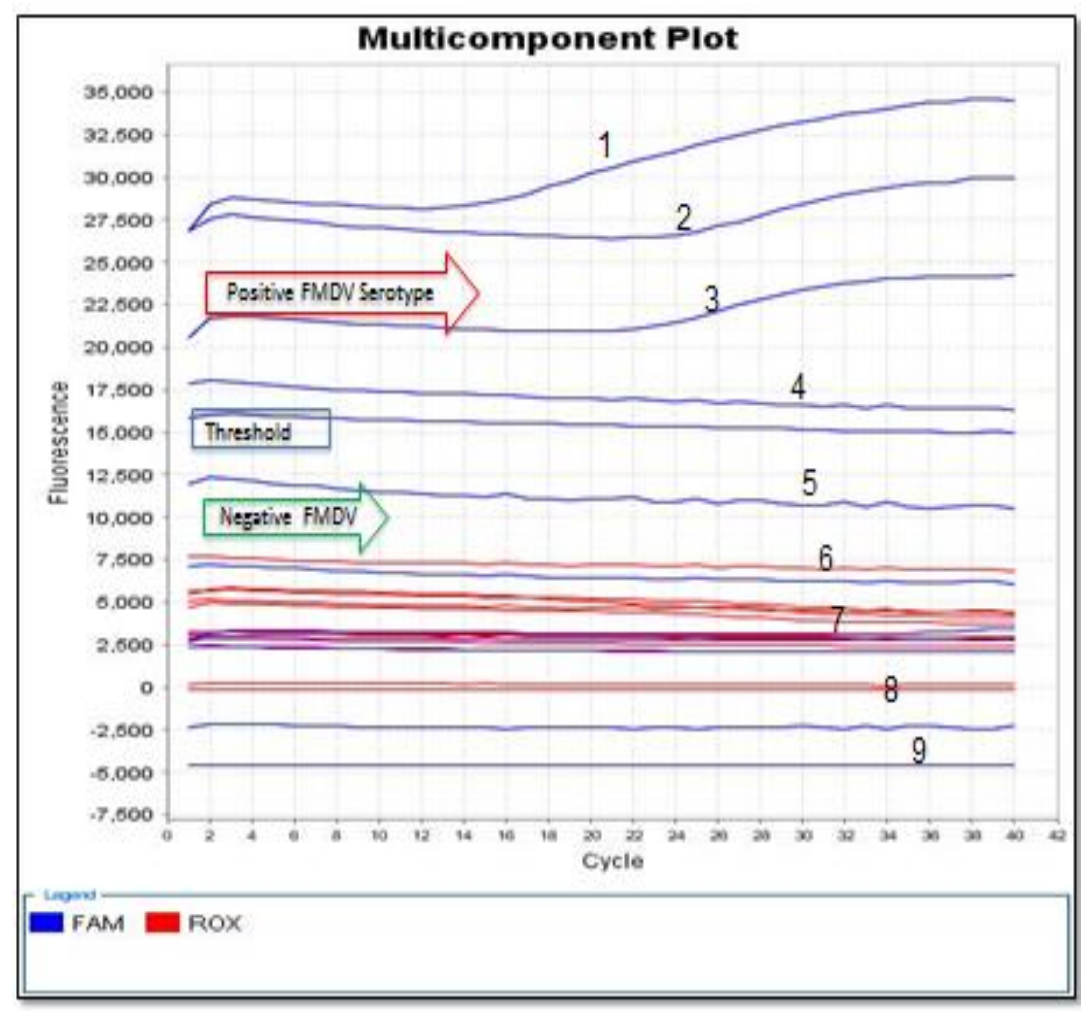

Figure 6. Differentiation of foot and mouth disease virus serotypes SAT2, O and A in tissue samples of infected cattle and buffaloes. Ct 1 positive FMDV type SAT-2. Ct 2, 3, 4 showed positive tested samples collected from tongue tissue biopsy during FMD outbreaks. While Ct 5,6,7,8and 9 showed negative results did not reach the threshold are recorded negative results or "No cycle threshold (Ct)". FMDV: Foot -and Mouth Disease Virus; FAM: based probe complementary to only one of the genes and SYBR Green I as an intercalating dye; $\mathrm{Ct}$ : cycle threshold; ROX: normalization $0.5 \mu \mathrm{l}$, ROX ( 5 x concentration) (6-Carboxyl-X-Rhodamine max - 610nm); ROX can inhibit PCR if the concentration is too high

Real-time reverse transcriptase Polymerase Chain Reaction (RT-PCR) detected 54 positive Foot -and Mouth Disease Virus in suspected samples of cattle and buffaloes as demonstrated in figure 5 and figure 6. FMDV positive results above the cycle threshold $(\mathrm{Ct})$ and negative below the cycle threshold $(\mathrm{Ct})$ are presented. $\mathrm{Ct} 1$ showed postive control for all FMDV serotypes using univesial primers, Ct 2 and 3 showed positive samples for FMDV, while Ct 4 and 5 showed negative results. The fluorescence signal accumulated during amplification crosses the cycle threshold ( $\mathrm{Ct}$ ) value. A cycle threshold $(\mathrm{Ct})$ value is calculated at the end of the assay. Negative results (for assays that did not reach the threshold) are recorded negative results or "No cycle threshold (Ct)".

Results of rRTPCR were indciated in less than five hours for collected tissue samples. High evident rRT-PCR results associated with samples that had CT values above the diagnostic threshold CT was sufficient for the confirmation of FMDV prevalence, this study had a beneficial result where FMD was endemic. Also, rRT-PCR able to identify and characterized different FMDV serotypes causes outbreaks (Bachanek-Bankowska et al., 2018). RRT-PCR results was similar to the result obtained by 3ABC ELISA and RT PCR. The negative results were likely to occur in cattle recovered from clinical lesions since the virus was extremely reduced with 7-10 days after the appearance of gross lesions as shown in table 3 and this result was in agreement with (Paixao et al., 2008; Lee et al., 2011). In addition, cattle and buffaloes can become carriers, and also can harbor the virus for up to three years (Locher et al., 1995; Longjam et al., 2011). Finally, prevalence of FMD in Egypt at 2017 may be related to several causes which included insufficiency of the vaccination program, improper inactivated FMDV vaccine, as well as imported cattle from Ethiopia or different Africans countries which endemic with FMDV due to the genetic mutation of the FMDV, can be dedicated that the FMD virus produces a new antigenic structure that can be escaped from the animal immune system. Also, no cross-protection between the different FMDV serotypes was indicated.

\section{CONCLUSION}

This study was proved that the FMDV serotypes O, A, and SAT2 have been occurred in cattle and buffalos in different governorates in Egypt at a period in the summer of 2017. FMDV is transboundary from neighbor countries or throughout the importation of carrier animals. the RT-RPA assay was developed for rapid and sensitive for identification of FMDV when compared to conventional RT-PCR, 3-ABC-ELISA, and Sn-ELISA. 


\section{Acknowledgments}

The authors are thankful to veterinary research division, National Research Centre, Dokki, Egypt and department of biotechnology, animal health institute, Dokki, Egypt, for providing required and materials during this work. Also, many thanks for Dr. Mohammed Gamal El-Hamady for his help and cooperation in this work.

\section{Competing interests}

The authors declared that they have no competing interests.

\section{Author's contributions}

Dr. GSZ, research idea, planned the study design, performed statistical analysis, and field animal's samples collection, performed serological and molecular laboratory work, and drafting the paper. Dr. AMA, sharing in the conception of the research idea, field animal's samples collection, and participated in drafting the manuscript Dr. KA, involved in samples collection, laboratory work, interpreted the data results, and helped in manuscript preparation. All authors read and approved the final manuscript.

\section{REFERENCES}

Abd El Wahed A, El-Deeb A, El-Tholoth M, Abd El Kader H, Ahmed A, Hassan S, Hoffmann B, Haas B, Shalaby MA, Hufert FT and Weidmann M (2013). A Portable Reverse Transcription Recombinase Polymerase Amplification Assay for Rapid Detection of Foot-and-Mouth Disease Virus. PLoS ONE, 8: 1- 7. DOI: https:// 10.1371/journal.pone.0071642

Ahmed HA, Salem SA, Habashi AR, Arafa AA, Aggour MG, Salem GH, Gaber AS, Selem O, Abdelkader SH, Knowles NJ et al. (2012). Emergence of foot-and-mouth disease virus SAT 2 in Egypt during 2012. Transboundary and Emerging Diseases, 59: 476-481. DOI: https://10.1111/tbed.12015

Aktas MS, Ozkanlar Y, Oruc E, Sozdutmaz I and Kirbas A (2015). Myocarditis associated with foot and mouth disease in suckling calves. Veterinarski arhiv, 2015: 85:273-282.

Bachanek-Bankowska K, Di Nardo A, Wadsworth J, Henry EK, Parlak Ü, Timina A and Hossain MA (2018). Foot-and-Mouth Disease in the Middle East Caused by an A/ASIA/G-VII Virus Lineage, 2015-2016. Emerging infectious diseases, $24(6)$ : 1073. DOI: https:// 10.3201/eid2406.170715

Beck E and Strohmaier K (1987). Subtyping of European foot and mouth disease virus strains by approaches nucleotide sequence determination. Journal of Virology, 61:1621-1629.

Brooksby J (1958). The virus of foot-and-mouth disease. Advances in Virus Research, 5:1-37 DOI: https:// 10.1016/S00653527(08)60670-3

Callahan JD, Brown F, Osorio FA, Sur JH, Kramer E, Long GW, Lubroth J, Ellis SJ, Shoulars KS and Gaffney KL (2002). Use of a portable real-time reverse transcriptase polymerase chain reaction assay for rapid detection of foot-and-mouth disease virus. Journal of the American Veterinary Medical Association, 220: 1636-1642. DOI: https://10.2460/javma.2002.220.1636

Carrillo C, Tulman ER, Delhon G, Lu Z, Carreno A and Vagnozzi A (2005). Comparative genomics of foot and mouth disease virus. Journal of Virology, 7910:6487-6504. DOI: https://10.1128/JVI.79.10.6487-6504.2005

Diab E, Bazid AI, Fawzy M, El-Ashmawy WR, Fayed AA and El-Sayed MM (2019). Foot-and-mouth disease outbreaks in Egypt during 2013-2014: Molecular characterization of serotypes A, O, and SAT2. Veterinary World, 12(2): 190-197.

Domingo E and Holland JJ (1997). RNA virus mutations and fitness for survival. Annual Review of Microbiology, 51: 151-178. DOI:https:// 10.1146/annurev.micro.51.1.151

El Bahgy HE and Moustafa MM (2018). ELISA, RT-PCR, semi-quantitative RT-PCR and sequencing methods for investigating an epidemic FMD virus serotype O outbreaks. African Journal of Biotechnology, 17(15): 505-514.

Elhaig MM and Elsheery MN (2014). Molecular investigation of foot-and-mouth disease virus in domestic bovids from Gharbia, Egypt. Tropical Animal Health and Production, 46: 1455-1462. DOI:https:// 10.1007/s11250-014-0665-7

El-Khabaz KAS and Al-Hosary AAT (2017). Detection and identification of Foot and Mouth disease virus serotypes in Assiut governorate, Egypt. Journal of Advanced Veterinary and Animal Research, 4: 32-38.

EL-Kholy AA, Soliman HMT and Abdel Rahman AO (2007). Molecular Typing of a new foot-and-mouth disease virus in Egypt. Veterinary Record, 160: 695-697.

EL-Shehawy L, Abu-Elnaga H, Talat A, EL-Garf E, Zakaria A and Azab AA (2011) Nucleotide sequencing of foot-and-mouth disease virus Egyptian strains. Journal of American Science, 7: 430-434.

FAO (2012). Foot-and-Mouth Disease Caused by Serotype SAT2 in Egypt and Libya: A Regional Concern for Animal Health in North Africa and the Middle East. EMPRES Watch Volume 25, March, 2012. Food and Agriculture Organization of the United Nations, Rome, Italy, pp. 1-7.

Grubman MJ and Baxt B (2004). Foot-and-mouth disease. Clinical Microbiology Reviews, 17: 465-493. DOI:https:// 10.1128/CMR.17.2.465.

Jamal SM and Belsham GJ (2018). Molecular epidemiology, evolution and phylogeny of foot-and-mouth disease virus. Infection, Genetics and Evolution, 59: 84-98. 
Kandeil A, EL-Shesheny R, Kayali G, Moatasim Y, Bagato O, Darwish M, Gaffar A, Younes A, Farag T and Kutkat MA (2013). Characterization of the recent outbreak of foot-and-mouth disease virus serotype SAT2 in Egypt. Archives of virology, 158: 619627.

Khodary MG, El-Deeb AH, Emara MM, Othman OE and Hussein AH (2018). Molecular characterization of foot and mouth disease virus (O-EA3) isolated during 2016 outbreak in Egypt. Journal of Virological Sciences (1): 1-9.

King AM, Lefkowitz E, Adams MJ and Carstens EB (2011). Virus taxonomy: ninth report of the International Committee on Taxonomy of Viruses. Elsevier Academic, 9: 193-210.

King DP, Ferris NP, Shaw AE, Reid SM, Hutchings GH, Giuffre AC, Robida JM, Callahan JD, Nelson WM and Beckham TR (2006). Detection of foot-and mouth disease virus: comparative diagnostic sensitivity of two independent real-time reverse transcriptionpolymerase chain reaction assays. Journal of Veterinary Diagnostic Investigation, 18: 93-97. DOI:https:// $10.1177 / 104063870601800114$

Knowles NJ, He J, Shang Y, Wadsworth J, Valdazo-González B and Onosato H (2012). Southeast Asian foot and mouth disease viruses in Eastern Asia. Emerging Infectious Diseases journal, 18:499-501. DOI: https://10.3201/eid1803.110908

Lee KN, Nguyen T, Kim SM, Cho IS, Van Quyen D, Khang DD and Park JH (2011). Development of one-step multiplex RT-PCR method for simultaneous detection and differentiation of foot-and-mouth disease virus serotypes $\mathrm{O}$, A and Asia circulating in Vietnam. Journal of Virological Methods, 175:1:101-108. DOI: https://10.1016/j.jviromet.2011.04.027

Lloyd-Jones K, Mahapatra M, Upadhyaya S, Paton DJ, Babu A, Hutchings G and Parida S (2017). Genetic and antigenic characterization of serotype O FMD viruses from East Africa for the selection of suitable vaccine strain. Vaccine, 35(49): 68426849.

Locher F, Suryanarayana VVS and Tratschin JD (1995). Rapid detection and characterization of Foot-and- Mouth Disease virus by restriction enzyme and nucleotide sequence analysis of PCR products. Journal of Clinical Microbiology, 33: 440-444.

Longjam N, Sarmah AK, Deb R, Mathapati B, Saxena VK and Tayo T (2011). Detection of foot and mouth disease virus serotype O by sandwich ELISA, viral isolation and multiplex PCR. Online Journal of Veterinary Research, 15(1):76-92.

OIE (2009). OIE - World Organization for Animal Health. Foot and Mouth Disease OIE Terrestrial Manual 2009, Chapter 2.1.5: 1-29

Paixao TA, Neta AVC, Paiva NO, Reis JR, Barbosa MS, Serra CV, Silva RR, Beckham TR, Martin BM, Clarke NP et al. (2008). Diagnosis of foot-and mouth disease by real time reverse transcription polymerase chain reaction under field conditions in Brazil. BMC Veterinary Research, 4: 53- 58. DOI: https://10.1186/1746-6148-4-53.

Radostitis OM, Gay CC, Hinchcliff KW and Constable PD (2007). Veterinary medicine. A text book of the diseases of cattle, horses, sheep, pigs and goats, 10th edition, Saunders Elsevier, Edinburgh, London, New york, Oxford . 10th edn., Elsevier Health Sciences, Philadelphia, 337-335.

Rady AA, Khalil SA and Torky HA (2014). Molecular Epidemiology of FMDV in Northern Egypt (2012-214). Alexandria Journal of Veterinary Sciences, 41: 120-130. DOI: https://10.5455/ajvs.157989

Reid SM, Parida S, King DP, Hutchings GH, Shaw AE, Ferris NP, Zhang Z, Hillerton JE and Paton DJ (2006). Utility of automated real-time RT-PCR for the detection of foot-and-mouth disease virus excreted in milk. Veterinary Research, 37: 121-132. DOI: https://10.1051/vetres:2005040

Salam HM, Mahmoud AA, Khadr AM, Salem SA, Elshemey TM and Abdelrahman AH (2014). Isolation, sequencing and phylogenetic analysis of FMD strains during 2011-2012 outbreaks in Egypt. International Journal of Agriculture Innovations and Research, 3(4): 1023-1038. DOI:https:// 10.5455/jva.20130219104353

Shawky M, Abd El-Aty M, Hiam MF, Hind MD, Ehab EI, Wael MG, Sonia AR, Abu-Elnaga H, Mohamed A A, Abd El-kreem A and Farouk EM (2013). Isolation and Molecular Characterization of Foot and Mouth Disease SAT2 Virus during Outbreak 2012 in Egypt. Journal of Veterinary Advances, 3: 60-68. DOI:https:// 10.5455/jva.20130219104353

Sobhy NM, Mor SK, Mohammed MEM, Bastawecy IM, Fakhry HM and Youssef CRB (2014). Phylogenetic analysis of Egyptian foot and mouth disease virus endemic strains. Journal of American Science, 10:133-138. Doi: https:// 10.1016/j.ijvsm.2018.02.001

Sobhy NM, YH Bayoumi, SK Mor, HI El-Zahar and SM Goyal (2018). Outbreaks of foot and mouth disease in Egypt: Molecular epidemiology, evolution and cardiac biomarkers prognostic significance. International Journal of Veterinary Science and Medicine, 6: 22-30. DOI: https://10.1016/j.ijvsm.2018.02.001

Sohair RF and Khadiga- Gaafar (2016). Establishing the first institutional animal care and use committee in Egypt. Philosophy, Ethics, and Humanities in Medicine, 11:1: 2. DOI: https:// 10.1186/s13010-016-0035-3

Stram Y, Molad T, Chai D, Gelman B and Yadin H (1995). Detection and subtyping of foot-and mouth disease virus in infected cattle by polymerase chain reaction and amplified VP1 sequencing. Journal of Veterinary Diagnostic Investigation, 7:52-55. DOI: https:// 10.1177/104063879500700107

Vallat B, Domenech J and Schudel AA (2017). The Role of international organizations in the control of foot-and-mouth. Foot-andMouth Disease Virus, 409. DOI: https:// 10.21775/9781910190517.17

Yang M, Goolia M, Xu W, Bittner H and Clavijo A (2013). Development of a quick and simple detection methodology for foot and mouth disease virus serotypes O, A and Asia 1 using a generic Rapid Assay Device. Virology Journal, 10: 125. DOI: https:// $10.1186 / 1743-422 \mathrm{X}-10-125$ 